University of Wollongong

Research Online

Faculty of Engineering - Papers (Archive)

Faculty of Engineering and Information

Sciences

$1-1-2010$

\title{
Carbothermal reduction of a primary ilmenite concentrate in different gas atmospheres
}

Mohammad A. R Dewan

University of New South Wales

Guangqing Zhang

University of Wollongong, gzhang@uow.edu.au

Oleg Ostrovski

University of New South Wales

Follow this and additional works at: https://ro.uow.edu.au/engpapers

Part of the Engineering Commons

https://ro.uow.edu.au/engpapers/4444

\section{Recommended Citation}

Dewan, Mohammad A. R; Zhang, Guangqing; and Ostrovski, Oleg: Carbothermal reduction of a primary ilmenite concentrate in different gas atmospheres 2010, 182-192.

https://ro.uow.edu.au/engpapers/4444

Research Online is the open access institutional repository for the University of Wollongong. For further information contact the UOW Library: research-pubs@uow.edu.au 


\title{
Carbothermal Reduction of a Primary Ilmenite Concentrate in Different Gas Atmospheres
}

\author{
MOHAMMAD A.R. DEWAN, GUANGQING ZHANG, and OLEG OSTROVSKI
}

\begin{abstract}
The carbothermal reduction of a primary ilmenite concentrate was studied in hydrogen, argon, and helium. Ilmenite and graphite were uniformly mixed and pressed into pellets. Reduction was studied in isothermal and temperature-programmed reduction experiments in a tube reactor with continuously flowing gas. $\mathrm{CO}, \mathrm{CO}_{2}$, and $\mathrm{CH}_{4}$ contents in the off-gas were measured online using infrared sensors. The phase composition of reduced samples was characterized by X-ray diffraction (XRD). Oxygen and carbon contents in reduced samples were determined by LECO analyzers (LECO Corporation, St. Joseph, MI). The main phases in the ilmenite concentrate were ilmenite and pseudorutile. The reaction started with the reduction of pseudorutile to ilmenite and titania, followed by the reduction of ilmenite to metallic iron and titania. Titania was reduced to $\mathrm{Ti}_{3} \mathrm{O}_{5}$ and even more to $\mathrm{Ti}_{2} \mathrm{O}_{3}$, which was converted to titanium oxycarbide. Reduction was faster in hydrogen than in helium and argon, which was attributed to involvement of hydrogen in the reduction reactions. The formation of titanium oxycarbide in hydrogen started at $1000^{\circ} \mathrm{C}$ and was completed in 300 minutes at $1200{ }^{\circ} \mathrm{C}$, and 30 minutes at $1500{ }^{\circ} \mathrm{C}$. The formation of titanium oxycarbide in argon and helium started at $1200{ }^{\circ} \mathrm{C}$ and was not completed after 300 minutes at $1300{ }^{\circ} \mathrm{C}$.
\end{abstract}

DOI: $10.1007 / \mathrm{s} 11663-009-9308-1$

(C) The Minerals, Metals \& Materials Society and ASM International 2009

\section{INTRODUCTION}

Metallic titanium and titania white pigment are produced from titanium tetrachloride, which is obtained by the chlorination of high-quality titania ores or synthetic rutile and slag with high titania contents. Ilmenite ore is the main titanium resource, which consists of titanium and iron oxides and impurities, such as $\mathrm{MnO}, \mathrm{SiO}_{2}, \mathrm{MgO}, \mathrm{Al}_{2} \mathrm{O}_{3}, \mathrm{CaO}, \mathrm{V}_{2} \mathrm{O}_{5}, \mathrm{Cr}_{2} \mathrm{O}_{3}$, and others. ${ }^{[1]}$ It is necessary to remove iron from ilmenite ores to obtain titanium-rich material for chlorination. Many methods have been proposed to refine ilmenite, including smelting, direct acid leaching, selective chlorination, and reduction. ${ }^{[2-5]}$ Selective reduction of iron oxides and following leaching, such as the Becher process, is one of the most effective technologies to produce synthetic rutile.

Merk and Pickles ${ }^{[6]}$ studied the reduction of ilmenite by carbon monoxide at $500{ }^{\circ} \mathrm{C}$ to $1100{ }^{\circ} \mathrm{C}$. The increase in temperature had a significant effect on the reduction rate. The reduction rate and final degree of reduction were affected by the formation of a metallic shell of iron that inhibited the transfer of $\mathrm{CO}$ to the reaction zone. By ball milling of the carbon-ilmenite mixture, Chen et al. ${ }^{[7]}$ decreased the temperature of the carbothermal reduction of mineral ilmenite to rutile and metallic iron. A longer milling time resulted in a lower reduction

MOHAMMAD A.R. DEWAN, Research Associate, GUANGQING ZHANG, Lecturer, and OLEG OSTROVSKI, Professor, are with the School of Materials Science and Engineering, University of New South Wales, UNSW, Sydney, NSW 2052, Australia. Contact e-mail: m.dewan@student.unsw.edu.au.

Manuscript submitted May 25, 2009.

Article published online September 29, 2009. temperature and a higher reduction rate. Park and Ostrovski ${ }^{[8,9]}$ studied the reduction of titaniferrous ore using a $\mathrm{H}_{2}$ - $\mathrm{Ar}$ gas mixture in the temperature range from $700{ }^{\circ} \mathrm{C}$ to $1100{ }^{\circ} \mathrm{C}$ and a $\mathrm{CO}-\mathrm{Ar}-\mathrm{CO}_{2}$ gas mixture at $1100{ }^{\circ} \mathrm{C}$ to $1200{ }^{\circ} \mathrm{C}$. A rise in the temperature as well as in the hydrogen or carbon monoxide content in the atmospheres increased the reduction rate.

The chlorination of titania requires a high temperature of $800{ }^{\circ} \mathrm{C}$ to $1100{ }^{\circ} \mathrm{C}$. Impurities are also chlorinated in this temperature range. However, titanium carbide or oxycarbide can be chlorinated at low temperatures, ${ }^{[10]}$ at which the chlorination of impurities can be avoided. Therefore, requirements of materials to be chlorinated can be released, so that titanium resources are used more effectively. The carbothermal reduction of ilmenite to titanium oxycarbide was studied.$^{[11-17]}$ Terry and Chinyamakobvu ${ }^{[12]}$ investigated the production of titanium oxycarbide-iron composites by carbothermal reduction of ilmenite with coal in flowing argon. They reported an excellent dispersion of $\mathrm{Ti}(\mathrm{O}, \mathrm{C})$ in an $\mathrm{Fe}$ matrix at temperatures above $1450{ }^{\circ} \mathrm{C}$. Coley et al. ${ }^{[1]}$ reduced Western Australia ilmenite using collie coal at $1314{ }^{\circ} \mathrm{C}$ to $1517{ }^{\circ} \mathrm{C}$. It was suggested that titanium oxycarbide was formed from $\mathrm{Ti}_{3} \mathrm{O}_{5}$ at temperatures below $1413{ }^{\circ} \mathrm{C}$ and from $\mathrm{Ti}_{2} \mathrm{O}_{3}$ above the temperature. Welham and Williams ${ }^{[14]}$ reported the decrease of TiC formation temperature from ilmenite to $1100{ }^{\circ} \mathrm{C}$ by mechanical activation and suggested that iron promoted formation of $\mathrm{TiC}$ by enhancing carbon transport through the iron phase. They also suggested that TiC, rather than the oxycarbide phase, was formed by the carbothermal reduction of ilmenite. Wang and Yuan ${ }^{[18]}$ reported no formation of titanium oxycarbide in the carbothermal reduction of natural ilmenite up to 
$1400{ }^{\circ} \mathrm{C}$. There are still inconsistencies in understanding of the kinetics and mechanisms of the reduction of ilmenite. Zhang and Ostrovski ${ }^{[15-17]}$ investigated the reduction of natural, sintered, and preoxidized ilmenite concentrates in hydrogen-methane mixtures. The reduction of iron was completed at $950{ }^{\circ} \mathrm{C}$ for 180 minutes. The formation of titanium oxycarbide was close to completion at $1150{ }^{\circ} \mathrm{C}$ for 60 minutes. Recent works demonstrated that the kinetics of the carbothermal reduction of metal oxides is strongly affected by the gas atmospheres. ${ }^{[19-21]}$ This study examines the reduction of an ilmenite concentrate in hydrogen, helium, and argon gases, as well as the changes of phase composition in the course of the reduction process.

\section{EXPERIMENTAL}

The ilmenite concentrate used in this investigation was the primary ilmenite supplied by Iluka Resources Limited (Perth, Western Australia). The chemical composition of the ilmenite concentrate is presented in Table I. It contained $53.9 \mathrm{wt}$ pct of $\mathrm{TiO}_{2}$; the particle size was in the range of 50 to $300 \mu \mathrm{m}$ with an average size of $152 \mu \mathrm{m}$. As-received ilmenite particles and synthetic graphite ( 99.5 pct purity, $<20 \mu \mathrm{m}$ in particle size, supplied by Sigma Aldrich, Castle Hill, Australia) were wet mixed and pressed into cylindrical pellets. ${ }^{[19]}$ The ilmenite-graphite mixture contained $10 \mathrm{~mol}$ pct extra graphite to the stoichiometric amount of carbon necessary to reduce the oxides of titanium, iron, and manganese present in the ilmenite. Other oxides were considered to be unreducible under given experimental conditions. The pellets with a mass of about $2 \mathrm{~g}$ were $8 \mathrm{~mm}$ in diameter and about $12 \mathrm{~mm}$ high.

The reduction of primary ilmenite by graphite in $\mathrm{H}_{2}$, Ar, and $\mathrm{He}$ gases was studied in a laboratory fixed-bed reactor in a vertical tube electric furnace. The experimental setup and gas systems were presented elsewhere. ${ }^{[2]}$ The gases used in the investigation were of 99.999 pct purity. The outlet gas was analyzed online by an infrared $\mathrm{CO} / \mathrm{CO}_{2} / \mathrm{CH}_{4}$ analyzer (Advanced Optima AO2020, ABB, Ladenburgh, Germany). The total gas flow rate was maintained at $1.00 \mathrm{NL} / \mathrm{min}$.

The reduced pellets were analyzed by X-ray diffraction (XRD) with Philips X'Pert-Pro MPD diffractometer (PANalytical, Lelyweg, the Netherlands) with $\mathrm{CuK} \alpha$ radiation. The oxygen and carbon contents in reduced samples were determined using LECO analyses (TC-436DR oxygen and nitrogen analyzer and CS-444 carbon and sulfur analyzer).

The extent of reduction was defined as a fraction of oxygen in titanium, iron, and manganese oxides removed in the course of reduction, and it was calculated based on the gas composition as well as the oxygen and carbon contents of reduced samples. The error of measured oxygen content by LECO analysis depends on the residual oxygen content in the reduced sample. For a sample with an extent of reduction 90 pct, the error was about 0.1 pct, which gave an error in the extent of reduction 0.3 pct. Including other errors such as in weighing and gas flow rate, the overall error of the final extent of reduction was estimated to be less than 1 pct.

\section{RESULTS}

\section{A. Temperature-Programmed Reduction}

Temperature-programmed reduction (TPR) experiments were carried out in a temperature range from $350{ }^{\circ} \mathrm{C}$ to $1600{ }^{\circ} \mathrm{C}$, with heating rate of $3{ }^{\circ} \mathrm{C} / \mathrm{min}$.

Figure 1 compares the rates of reduction characterized by the rates of evolution of $\mathrm{CO}$ in reduction experiments in different gas atmospheres. When the reduction was in hydrogen, water was also evolved as presented in Figure 1. In the reduction experiments in argon or helium, the concentration of water vapor in the off-gas was negligible.

In general, the reduction curves in hydrogen consist of two water peaks in a low temperature range, followed by a main peak of $\mathrm{CO}$ formation. In comparison, the reduction curves in helium and argon consist of two overlapped $\mathrm{CO}$ peaks, which appear in a higher temperature range than that in hydrogen. To reveal the essence of reduction in different gas atmospheres, reduction experiments were stopped at different stages, and the samples were subjected to XRD analysis.

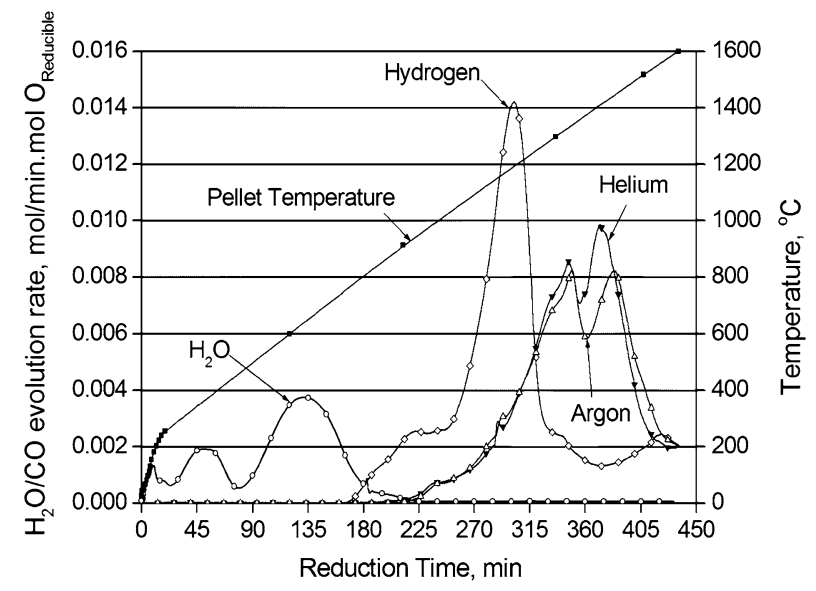

Fig. 1-Temperature programmed reduction of primary ilmenite in different gas atmospheres. The furnace temperature was ramped from $350{ }^{\circ} \mathrm{C}$ to $1600{ }^{\circ} \mathrm{C}$ at $3{ }^{\circ} \mathrm{C} / \mathrm{min}$.

Table I. Chemical Composition of Primary Ilmenite Concentrate

\begin{tabular}{lllllllll}
\hline Component & $\mathrm{TiO}_{2}$ & $\mathrm{~T}$ tal Fe & $\mathrm{FeO}$ & $\mathrm{Fe}_{2} \mathrm{O}_{3}$ & $\mathrm{MnO}$ & $\mathrm{SiO}_{2}$ & $\mathrm{ZrO}_{2}$ & $\mathrm{P}_{2} \mathrm{O}_{5}$ \\
Wt pct & 53.9 & 30.5 & 18.0 & 23.6 & 1.63 & 0.27 & 0.09 & 0.01 \\
Component & $\mathrm{Al}_{2} \mathrm{O}_{3}$ & $\mathrm{~S}$ & $\mathrm{Nb}_{2} \mathrm{O}_{5}$ & $\mathrm{Cr}_{2} \mathrm{O}_{3}$ & $\mathrm{CaO}$ & $\mathrm{MgO}$ & $\mathrm{V}_{2} \mathrm{O}_{5}$ & $\mathrm{Ti} / \mathrm{Fe}$ \\
Wt pet & 0.40 & 0.004 & 0.10 & 0.047 & $<0.01$ & 0.18 & 0.17 \\
\hline
\end{tabular}


Figure 2 presents the XRD patterns of the samples in progress of reduction in hydrogen. The phases detected by XRD in the samples reduced in hydrogen and argon to different temperatures are summarized in Table II.

As shown in Figure 2, the primary ilmenite concentrate contained mainly ilmenite and pseudorutile phases. The phases in naturally occurred ilmenite did not crystallize well and exhibited relatively weak XRD

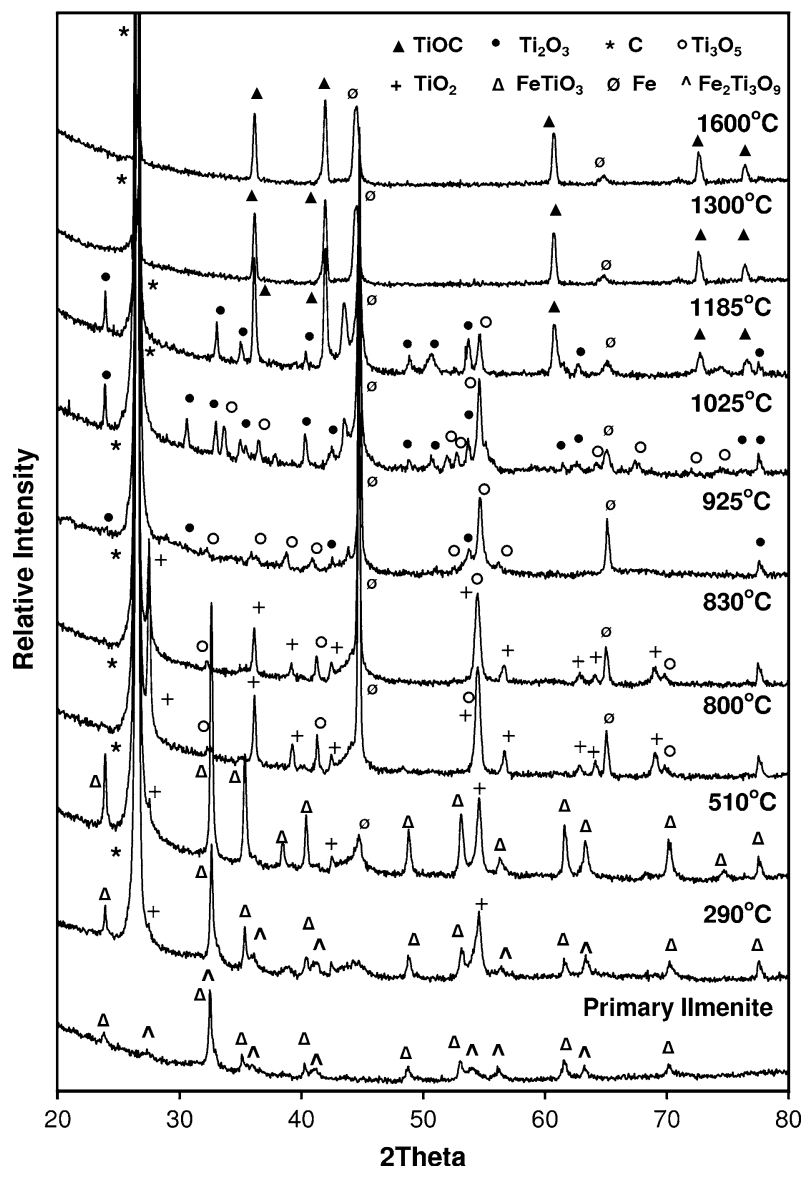

Fig. 2-XRD patterns of primary ilmenite in the progress of temperature programmed reduction in hydrogen. The furnace temperature was ramped at $3{ }^{\circ} \mathrm{C} / \mathrm{min}$. peaks; other phases than ilmenite and pseudorutile may exist but were not detected. When reduction was carried out in hydrogen, the reaction started with reduction by hydrogen. The small water peak at the very beginning of reduction when temperature was below $200{ }^{\circ} \mathrm{C}$ probably was from the release of physically adsorbed moisture in samples and the reaction system. The following peak until $510{ }^{\circ} \mathrm{C}$ represents the first stage of hydrogen reduction, with a maximum value

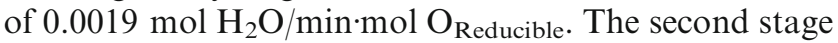
of reduction by hydrogen produced an $\mathrm{H}_{2} \mathrm{O}$ peak with reduction rate of $0.0037 \mathrm{~mol} / \mathrm{min} \cdot \mathrm{mol} \mathrm{O}_{\text {Reducible at }}$ $630{ }^{\circ} \mathrm{C}$. This stage lasted until $960{ }^{\circ} \mathrm{C}$, which slightly overlapped with evolution of $\mathrm{CO}$ starting at $780^{\circ} \mathrm{C}$. In the sample reduced to $290{ }^{\circ} \mathrm{C}$, peaks of titania appeared in addition to the original peaks of ilmenite and pseudorutile phases. At $510{ }^{\circ} \mathrm{C}$, peaks for titania, and especially for ilmenite, obviously became stronger, and those for pseudorutile disappeared. The first stage of reduction by hydrogen with $\mathrm{H}_{2} \mathrm{O}$ evolution corresponds to reduction of pseudorutile:

$$
\mathrm{Fe}_{2} \mathrm{Ti}_{3} \mathrm{O}_{9}+\mathrm{H}_{2} \rightarrow 2 \mathrm{FeTiO}_{3}+\mathrm{TiO}_{2}+\mathrm{H}_{2} \mathrm{O}
$$

At $510{ }^{\circ} \mathrm{C}$, a weak peak for metallic iron also appeared at 2theta $=44.9 \mathrm{deg}$, indicating beginning of metallization. At $800{ }^{\circ} \mathrm{C}$, the ilmenite peaks were undetectable, whereas the peaks for metallic iron and titania became stronger. This corresponds to the reduction of ilmenite by hydrogen:

$$
\mathrm{FeTiO}_{3}+\mathrm{H}_{2} \rightarrow \mathrm{Fe}+\mathrm{TiO}_{2}+\mathrm{H}_{2} \mathrm{O}
$$

$\mathrm{CO}$ evolution in hydrogen started at about $780{ }^{\circ} \mathrm{C}$, with an overlapped smaller peak preceding the main peak. Between $800{ }^{\circ} \mathrm{C}$ and $1025^{\circ} \mathrm{C}$, titania peaks in Figure 2 became weaker and then disappeared, which corresponds to the appearance of new phases of $\mathrm{Ti}_{3} \mathrm{O}_{5}$ and $\mathrm{Ti}_{2} \mathrm{O}_{3}$.

The reduction of titania to $\mathrm{Ti}_{3} \mathrm{O}_{5}$ and then to $\mathrm{Ti}_{2} \mathrm{O}_{3}$ can be by hydrogen or carbon. An experiment was carried out with a pellet of primary ilmenite without mixing of graphite. Figure 3 compares the curves of $\mathrm{H}_{2} \mathrm{O}$ evolution in experiments with and without graphite. The two main peaks of $\mathrm{H}_{2} \mathrm{O}$ evolution coincided.

Table II. Phase Composition of Primary Ilmenite Reduced in Hydrogen and Argon to Different Temperatures in Temperature

\begin{tabular}{|c|c|c|c|c|c|c|c|c|}
\hline Temperature, ${ }^{\circ} \mathrm{C}$ & 290 & 510 & 800 & 830 & 925 & 1025 & 1185 & 1600 \\
\hline $\mathrm{H}_{2}$ & $\begin{array}{l}\mathrm{C} \\
\mathrm{FeTiO}_{3} \\
\mathrm{Fe}_{2} \mathrm{Ti}_{3} \mathrm{O}_{9} \\
\mathrm{TiO}_{2}\end{array}$ & $\begin{array}{l}\mathrm{C} \\
\mathrm{FeTiO}_{3} \\
\mathrm{TiO}_{2} \\
\mathrm{Fe}\end{array}$ & $\begin{array}{l}\mathrm{C} \\
\mathrm{Fe} \\
\mathrm{TiO}_{2} \\
\mathrm{Ti}_{3} \mathrm{O}_{5}\end{array}$ & $\begin{array}{l}\mathrm{C} \\
\mathrm{Fe} \\
\mathrm{TiO}_{2} \\
\mathrm{Ti}_{3} \mathrm{O}_{5}\end{array}$ & $\begin{array}{l}\mathrm{C} \\
\mathrm{Fe} \\
\mathrm{Ti}_{3} \mathrm{O}_{5} \\
\mathrm{Ti}_{2} \mathrm{O}_{3}\end{array}$ & $\begin{array}{l}\mathrm{C} \\
\mathrm{Fe} \\
\mathrm{Ti}_{2} \mathrm{O}_{3} \\
\mathrm{Ti}_{3} \mathrm{O}_{5}\end{array}$ & $\begin{array}{l}\mathrm{C} \\
\mathrm{Fe} \\
\mathrm{TiO}_{x} \mathrm{C}_{y} \\
\mathrm{Ti}_{2} \mathrm{O}_{3}\end{array}$ & $\begin{array}{l}\mathrm{TiO}_{x} \mathrm{C}_{y} \\
\mathrm{Fe} \\
\mathrm{C}\end{array}$ \\
\hline Temperature, ${ }^{\circ} \mathrm{C}$ & 1000 & 1220 & 1320 & 1370 & \multicolumn{2}{|c|}{1420} & 1600 & \\
\hline $\mathrm{Ar}$ & $\begin{array}{l}\mathrm{C} \\
\mathrm{FeTiO}_{3} \\
\mathrm{TiO}_{2}\end{array}$ & $\begin{array}{l}\mathrm{C} \\
\mathrm{Fe} \\
\mathrm{Ti}_{3} \mathrm{O}_{5} \\
\mathrm{Ti}_{2} \mathrm{O}_{3} \\
\mathrm{TiO}_{2}\end{array}$ & $\begin{array}{l}\mathrm{C} \\
\mathrm{Fe} \\
\mathrm{Ti}_{3} \mathrm{O}_{5} \\
\mathrm{Ti}_{2} \mathrm{O}_{3}\end{array}$ & $\begin{array}{l}\mathrm{C} \\
\mathrm{Fe} \\
\mathrm{Ti}_{2} \mathrm{O}_{3} \\
\mathrm{Ti}_{3} \mathrm{O}_{5} \\
\mathrm{TiO}_{x} \mathrm{C}_{y}\end{array}$ & \multicolumn{2}{|c|}{$\begin{array}{l}\mathrm{C} \\
\mathrm{Fe} \\
\mathrm{TiO}_{x} \mathrm{C}_{y} \\
\mathrm{Ti}_{2} \mathrm{O}_{3} \\
\mathrm{Ti}_{3} \mathrm{O}_{5}\end{array}$} & $\begin{array}{l}\mathrm{TiO}_{x} \mathrm{C}_{y} \\
\mathrm{Fe} \\
\mathrm{C} \\
\mathrm{Ti}_{2} \mathrm{O}_{3}\end{array}$ & \\
\hline
\end{tabular}
Programmed Reduction Experiments

Note: Phases are presented in the descending order in accordance with the relative intensity of XRD strongest peaks of individual phases. 


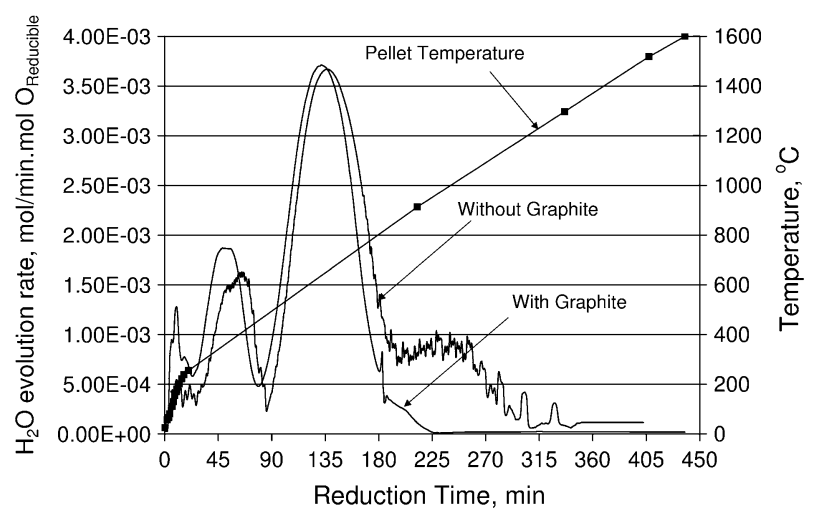

Fig. $3-\mathrm{H}_{2} \mathrm{O}$ evolution rate during temperature programmed reduction of primary ilmenite in hydrogen. The furnace temperature was ramped from $350{ }^{\circ} \mathrm{C}$ to $1600{ }^{\circ} \mathrm{C}$ at $3{ }^{\circ} \mathrm{C} / \mathrm{min}$.

The $\mathrm{H}_{2} \mathrm{O}$ evolution curve for the sample without graphite included an additional peak at elevated temperatures $900{ }^{\circ} \mathrm{C}$ to $1200{ }^{\circ} \mathrm{C}$. This peak was not observed in experiments with a ilmenite-graphite mixture because of water reaction with graphite. The final product of ilmenite reduction by hydrogen without graphite contained metallic iron and $\mathrm{Ti}_{2} \mathrm{O}_{3}$.

The reduction reactions by hydrogen in the presence of graphite can be presented as follows:

$$
\begin{gathered}
3 \mathrm{TiO}_{2}+\mathrm{H}_{2}=\mathrm{Ti}_{3} \mathrm{O}_{5}+\mathrm{H}_{2} \mathrm{O} \\
2 \mathrm{Ti}_{3} \mathrm{O}_{5}+\mathrm{H}_{2}=3 \mathrm{Ti}_{2} \mathrm{O}_{3}+\mathrm{H}_{2} \mathrm{O} \\
\mathrm{H}_{2} \mathrm{O}+\mathrm{C}=\mathrm{H}_{2}+\mathrm{CO}
\end{gathered}
$$

The subsequent reduction of $\mathrm{Ti}_{2} \mathrm{O}_{3}$ proceeded with carbon as a reductant with $\mathrm{CO}$ evolution. At $1185^{\circ} \mathrm{C}$, the maximum $\mathrm{CO}$ evolution rate of $0.0141 \mathrm{~mol} / \mathrm{min} \cdot \mathrm{mol}$ $\mathrm{O}_{\text {Reducible }}$ was achieved. A large amount of titanium oxycarbide phase was observed in the sample at this temperature, with unreduced titanium suboxides, $\mathrm{Ti}_{3} \mathrm{O}_{5}$, and $\mathrm{Ti}_{2} \mathrm{O}_{3}$. The rate of $\mathrm{CO}$ evolution sharply decreased after $1185^{\circ} \mathrm{C}$ because of depletion of titanium suboxides, and the reduction was completed at about $1300{ }^{\circ} \mathrm{C}$. $\mathrm{Ti}_{2} \mathrm{O}_{3}$ was reduced to $\mathrm{TiO}$ and $\mathrm{TiC}$, which formed the solid solution $\mathrm{TiO}_{x} \mathrm{C}_{y}$. The reduction reactions can be presented as:

$$
\begin{gathered}
\mathrm{Ti}_{2} \mathrm{O}_{3}+\mathrm{C}=2[\mathrm{TiO}]_{\mathrm{ss}}+\mathrm{CO} \\
\mathrm{Ti}_{2} \mathrm{O}_{3}+5 \mathrm{C}=2[\mathrm{TiC}]_{\mathrm{ss}}+3 \mathrm{CO}
\end{gathered}
$$

where subscript "ss" means a chemical in the solid solution. The subsequent extension of the slow evolution of $\mathrm{CO}$ may be attributed to the reduction of $\mathrm{TiO}$ from oxycarbide solid solution to form carbide:

$$
[\mathrm{TiO}]_{\mathrm{ss}}+2 \mathrm{C}=[\mathrm{TiC}]_{\mathrm{ss}}+\mathrm{CO}
$$

The reduction curves obtained in argon and helium were very similar. Reduction started at about $880{ }^{\circ} \mathrm{C}$. The first peak appeared at $1320{ }^{\circ} \mathrm{C}$, with a $\mathrm{CO}$ evolution rate of $0.0085 \mathrm{~mol} / \mathrm{min} \cdot \mathrm{mol} \mathrm{O}_{\text {Reducible }}$ in helium and $0.0081 \mathrm{~mol} / \mathrm{min} \cdot \mathrm{mol} \mathrm{O}_{\text {Reducible }}$ in argon. The second peak was at $1400{ }^{\circ} \mathrm{C}$ in helium and $1450{ }^{\circ} \mathrm{C}$ in argon. The maximum $\mathrm{CO}$ evolution rates corresponding to the second peak were $0.0097 \mathrm{~mol} / \mathrm{min} \cdot \mathrm{mol} \mathrm{O}_{\text {Reducible }}$ in helium and $0.0081 \mathrm{~mol} / \mathrm{min} \cdot \mathrm{mol} \mathrm{O}_{\text {Reducible }}$ in argon.

The XRD spectra of samples reduced in helium and in argon to the same stage were similar. The phases identified by the XRD analysis of samples in the progress of reduction in argon are also presented in Table II. When the temperature was ramped to $1000{ }^{\circ} \mathrm{C}$, strong peaks of $\mathrm{TiO}_{2}$ and ilmenite were observed, whereas the $\mathrm{Fe}_{2} \mathrm{Ti}_{3} \mathrm{O}_{9}$ phase became undetectable. At $1220{ }^{\circ} \mathrm{C}$, ilmenite was converted to metallic iron and titania was converted to $\mathrm{Ti}_{2} \mathrm{O}_{3}$ and $\mathrm{Ti}_{3} \mathrm{O}_{5}$. At $1320{ }^{\circ} \mathrm{C}$, corresponding to the first peak of $\mathrm{CO}$ evolution, the reduced sample consisted of $\mathrm{Fe}, \mathrm{Ti}_{2} \mathrm{O}_{3}, \mathrm{Ti}_{3} \mathrm{O}_{5}$, and carbon. At $1370{ }^{\circ} \mathrm{C}, \mathrm{TiO}_{x} \mathrm{C}_{y}$ became detectable, and its amount increased with boosting the reduction temperature to $1420{ }^{\circ} \mathrm{C}$ and then to $1600{ }^{\circ} \mathrm{C}$, at which the experiment was stopped. The final sample contained metallic iron, titanium oxycarbide, residual carbon, and $\mathrm{Ti}_{2} \mathrm{O}_{3}$. Therefore, the carburization of titanium was not completed until $1600{ }^{\circ} \mathrm{C}$. Basically, the carbothermal reduction of ilmenite concentrate in argon and helium followed the same sequence of reduction as in hydrogen. However, the reduction temperature needed for each step to occur was significantly higher in argon and helium than in hydrogen.

\section{B. Isothermal Reduction}

The effect of temperature on the extent of reduction of primary ilmenite concentrate was investigated in isothermal experiments, under hydrogen, argon and helium gas atmospheres. The extent of reduction of the primary ilmenite in different gases in the temperature range of $1000{ }^{\circ} \mathrm{C}$ to $1500{ }^{\circ} \mathrm{C}$ is presented in Figure 4 . The phase composition of samples reduced in hydrogen and argon at different temperatures for 300 minutes, identified by XRD, are summarized in Table III. The samples reduced in helium had the same phase composition as those reduced in argon.

The initial stage of the ilmenite reduction in hydrogen (Figure 4(a)) was fast because of iron oxide reduction. At $1000{ }^{\circ} \mathrm{C}$, the extent of reduction achieved $37 \mathrm{pct}$ within 30 minutes. However, the subsequent conversion of titanium oxide to oxycarbide was relatively slow. After 300 minutes of reduction at $1000{ }^{\circ} \mathrm{C}$, primary ilmenite was reduced to $\mathrm{Ti}_{2} \mathrm{O}_{3}, \mathrm{TiO}_{x} \mathrm{C}_{y}$ and metallic iron, with a total extent of reduction of 68 pct. Increasing the reduction temperature to $1100{ }^{\circ} \mathrm{C}$ significantly enhanced the formation of titanium oxycarbide. The extent of reduction increased to 89 pct, and a very small amount of residual $\mathrm{Ti}_{2} \mathrm{O}_{3}$ was detected in the sample reduced at $1100{ }^{\circ} \mathrm{C}$. Increasing the temperature even more to $1200{ }^{\circ} \mathrm{C}$ resulted in a significant increase of the rate and extent of reduction, in which the extent of reduction reached 95 pct after 300 minutes of reaction. $\mathrm{TiO}_{x} \mathrm{C}_{y}$ was identified as the only titanium compound. The reduction was enhanced by increasing the temperature to $1300{ }^{\circ} \mathrm{C}$ to $1500{ }^{\circ} \mathrm{C}$. At $1300{ }^{\circ} \mathrm{C}$, the formation 


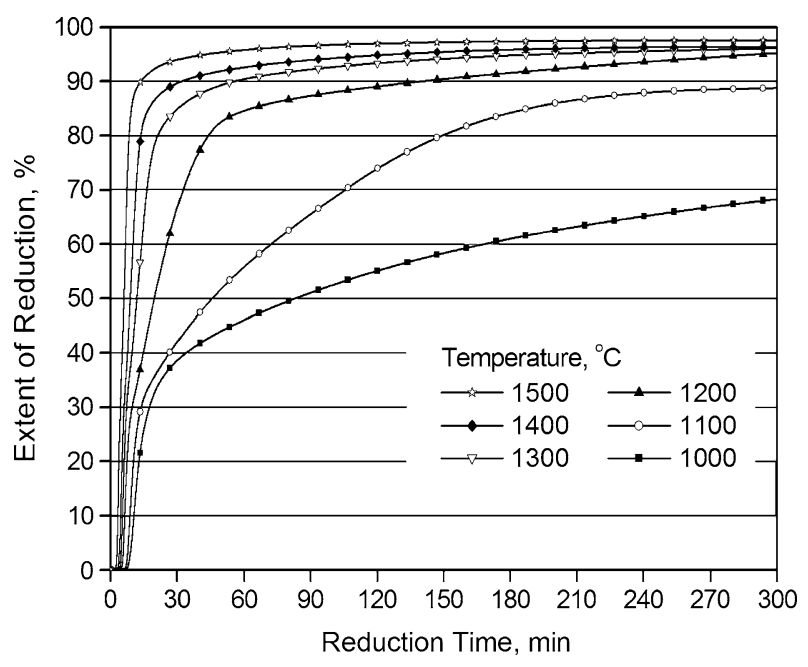

(a) Hydrogen

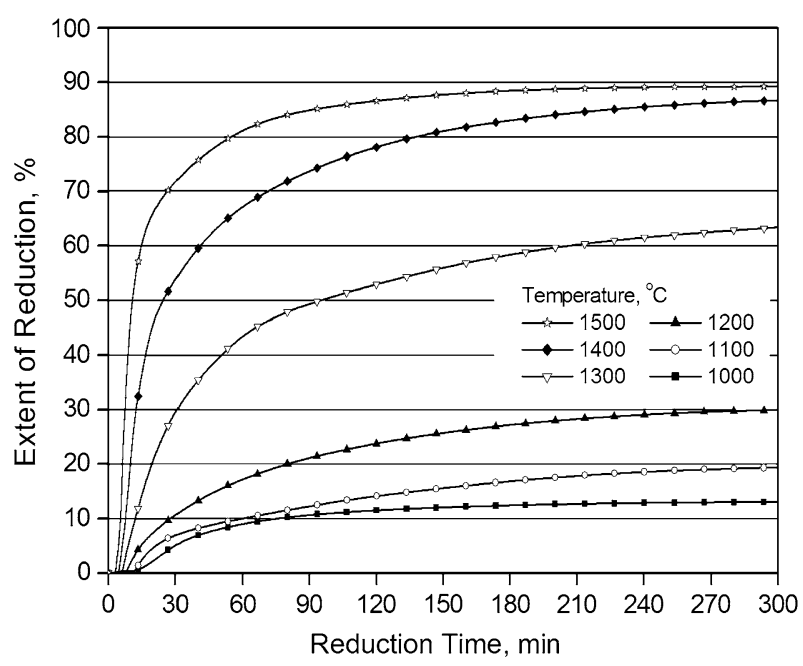

(b) Argon

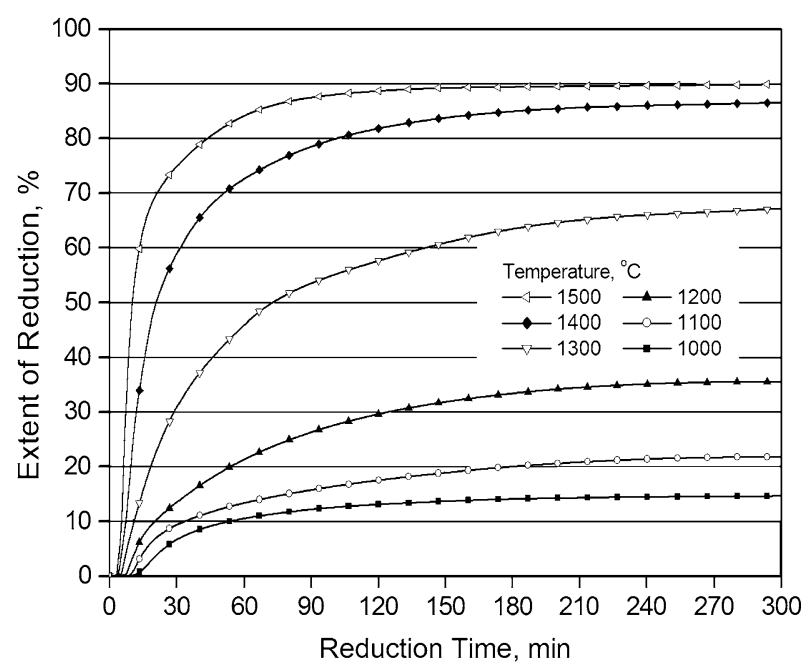

(c) Helium

Fig. 4-Effect of temperature on the extent of reduction of primary ilmenite in different gas atmospheres.
Table III. Phase Composition of Primary IImenite Reduced in Hydrogen or Argon at Different Temperatures for 300 Min

\begin{tabular}{lllllll}
\hline $\begin{array}{l}\text { Temperature } \\
\left({ }^{\circ} \mathrm{C}\right)\end{array}$ & 1000 & 1100 & 1200 & 1300 & 1400 & 1500 \\
\hline $\mathrm{H}_{2}$ & $\mathrm{C}$ & $\mathrm{C}$ & $\mathrm{C}$ & $\mathrm{Fe}$ & $\mathrm{TiO}_{x} \mathrm{C}_{y}$ & $\mathrm{TiO}_{x} \mathrm{C}_{y}$ \\
& $\mathrm{Fe}$ & $\mathrm{Fe}$ & $\mathrm{Fe}$ & $\mathrm{TiO}_{x} \mathrm{C}_{y}$ & $\mathrm{Fe}$ & $\mathrm{Fe}$ \\
& $\mathrm{Ti}_{2} \mathrm{O}_{3}$ & $\mathrm{TiO}_{x} \mathrm{C}_{y}$ & $\mathrm{TiO}_{x} \mathrm{C}_{y}$ & $\mathrm{C}$ & $\mathrm{C}$ & $\mathrm{C}$ \\
& $\mathrm{TiO} \mathrm{C}_{y}$ & $\mathrm{Ti}_{2} \mathrm{O}_{3}$ & & & & \\
$\mathrm{Ar}$ & $\mathrm{C}$ & $\mathrm{C}$ & $\mathrm{C}$ & $\mathrm{C}$ & $\mathrm{Fe}$ & $\mathrm{TiO}_{x} \mathrm{C}_{y}$ \\
& $\mathrm{FeTiO}_{3}$ & $\mathrm{Fe}$ & $\mathrm{Fe}$ & $\mathrm{Fe}$ & $\mathrm{TiO}_{x} \mathrm{C}_{y}$ & $\mathrm{Fe}$ \\
& $\mathrm{Fe}$ & $\mathrm{Ti}_{3} \mathrm{O}_{5}$ & $\mathrm{Ti}_{2} \mathrm{O}_{3}$ & $\mathrm{TiO}_{x} \mathrm{C}_{y} \mathrm{C}$ & $\mathrm{C}$ \\
& $\mathrm{TiO}_{2}$ & $\mathrm{TiO}_{2}$ & $\mathrm{Ti}_{3} \mathrm{O}_{5}$ & $\mathrm{Ti}_{2} \mathrm{O}_{3}$ & $\mathrm{Ti}_{2} \mathrm{O}_{3}$ & $\mathrm{Ti}_{2} \mathrm{O}_{3}$ \\
& & $\mathrm{FeTiO}_{3}$ & $\mathrm{TiO}_{x} \mathrm{C}_{y}$ & $\mathrm{Ti}_{3} \mathrm{O}_{5}$ & $\mathrm{Ti}_{3} \mathrm{O}_{5}$ & \\
& & & &
\end{tabular}

Note: The phases are presented in descending order in accordance with the relative intensity of XRD strongest peaks of individual phases.

of titanium oxycarbide completed in about 120 minutes, with an extent of reduction of 93.2 pct. The reduction period was shortened to 30 minutes at $1400{ }^{\circ} \mathrm{C}$ and the reduction extent reached 91 pct. At $1500{ }^{\circ} \mathrm{C}$, titania was converted to titanium oxycarbide in less than 30 minutes, which corresponds to the extent of reduction of 92 pct. However, the final extent of reduction after 300 minutes of reduction did not change significantly in the temperature range $1200{ }^{\circ} \mathrm{C}$ to $1500{ }^{\circ} \mathrm{C}$. This is consistent with the results of the reduction of rutile, ${ }^{[19]}$ as the removal of oxygen from the titanium oxycarbide phase by reaction [8] is slow.

When the carbothermal reduction was carried out in argon (Figure 4(b)), the reduction rate was significantly slower than in hydrogen. The carbothermal reduction of primary ilmenite was slow at $1000{ }^{\circ} \mathrm{C}$ to $1200{ }^{\circ} \mathrm{C}$. After 300 minutes reduction at $1000{ }^{\circ} \mathrm{C}$, an extent of reduction calculated from $\mathrm{CO}$ evolution was only 13 pct. XRD analysis detected $\mathrm{TiO}_{2}$, metallic iron and unconverted $\mathrm{FeTiO}_{3}$ (Table III). Titania was partially reduced to $\mathrm{Ti}_{3} \mathrm{O}_{5}$ at $1100{ }^{\circ} \mathrm{C}$ with an extent of reduction 19 pet. Conversion of ilmenite to metallic iron and titania was still incomplete. The titanium oxycarbide phase was first detected at $1200{ }^{\circ} \mathrm{C}$ after 300 minutes reduction, with $\mathrm{Ti}_{2} \mathrm{O}_{3}$ and $\mathrm{Ti}_{3} \mathrm{O}_{5}$ being the main titanium containing phases. Ilmenite was undetected by XRD, although the calculated extent of reduction, 30 pct, was lower than the level that corresponds to the complete reduction of iron oxides. A subsequent increase of reduction temperature to $1300{ }^{\circ} \mathrm{C}$ increased the extent of reduction to 63 pct; the reduction product contained $\mathrm{TiO}_{x} \mathrm{C}_{y}, \mathrm{Ti}_{2} \mathrm{O}_{3}$, $\mathrm{Ti}_{3} \mathrm{O}_{5}$, metallic iron, and residual graphite. The reduction was strongly enhanced by increasing the temperature to $1400{ }^{\circ} \mathrm{C}$ to $1500{ }^{\circ} \mathrm{C}$. At $1400{ }^{\circ} \mathrm{C}$, the extent of reduction continued to rise with increasing reduction time, reaching 87 pct in 300 minutes. The extent of reduction at $1500{ }^{\circ} \mathrm{C}$ achieved 87 pct in about 120 minutes, and it increased only slightly with the extension of reduction time. The $\mathrm{Ti}_{2} \mathrm{O}_{3}$ phase was still detectable in the samples reduced at $1400{ }^{\circ} \mathrm{C}$ and $1500{ }^{\circ} \mathrm{C}$ for 300 minutes. 
Figure 4(c) and (b) show that the reduction progressed slightly faster in helium than in argon. The extent of reduction achieved $87 \mathrm{pct}$ after 300 minutes at $1400{ }^{\circ} \mathrm{C}$ and 90 pet at $1500{ }^{\circ} \mathrm{C}$.

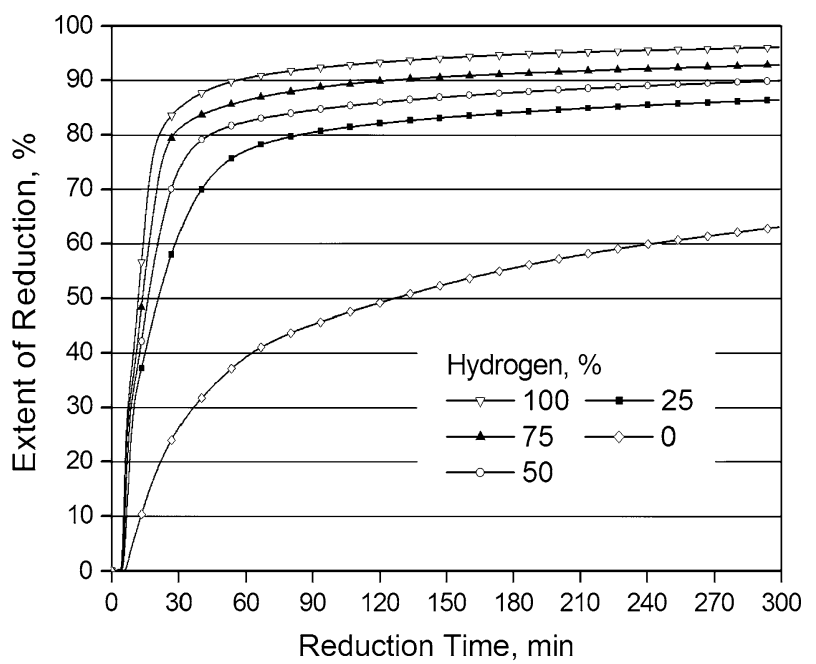

(a) Hydrogen-Argon mixtures

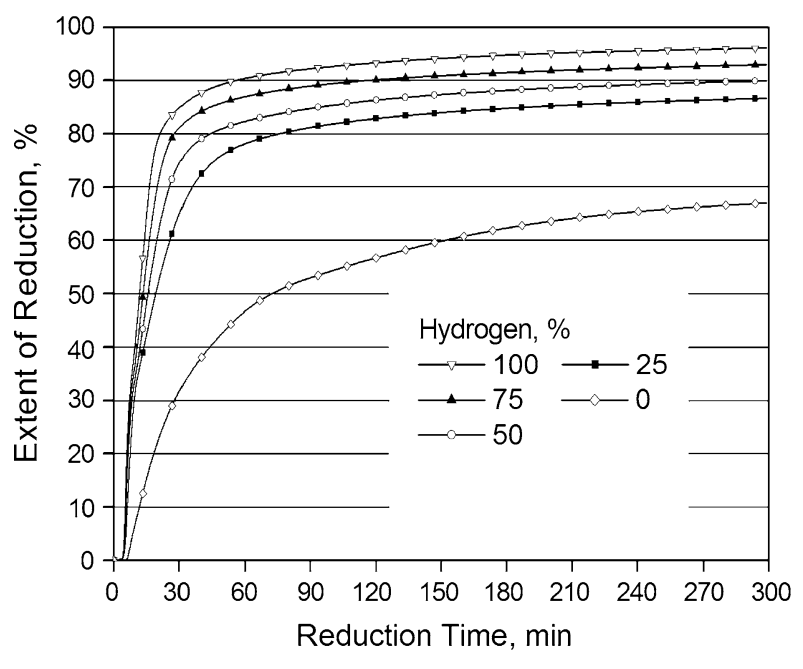

(b) Hydrogen-Helium mixtures

Fig. 5-Effect of hydrogen content in the $\mathrm{H}_{2}-\mathrm{Ar}$ and $\mathrm{H}_{2}-\mathrm{He}$ gas mixtures on reduction of primary ilmenite at $1300{ }^{\circ} \mathrm{C}$.
The effect of hydrogen content in $\mathrm{H}_{2}-\mathrm{Ar}$ and $\mathrm{H}_{2}-\mathrm{He}$ gas mixtures on the carbothermal reduction of primary ilmenite was examined at $1300{ }^{\circ} \mathrm{C}$. Reduction curves with different hydrogen content are presented in Figure 5. The extent of reduction in pure argon after 300 minutes of reaction was 63 pct (Figure 5(a)). The addition of $25 \mathrm{vol}$ pet hydrogen significantly increased the rate and extent of reduction. The final extent of reduction increased to $87 \mathrm{pct}$. The subsequent increase in hydrogen content to 50 to $100 \mathrm{vol}$ pct consistently accelerated the reduction process.

A similar effect of hydrogen was observed in the carbothermal reduction of primary ilmenite in the hydrogen-helium mixtures (Figure 5(b)). Generally, the extent of reduction curves obtained in experiments in $\mathrm{H}_{2}-\mathrm{Ar}$ and $\mathrm{H}_{2}-\mathrm{He}$ gas mixtures with the same hydrogen content were close.

\section{Phase Development in the Progress of Reduction}

In the reduction experiments at $1100{ }^{\circ} \mathrm{C}$ in hydrogen and at $1300{ }^{\circ} \mathrm{C}$ in argon and helium, the samples reduced for different time were analyzed by XRD. The phase composition of samples reduced in hydrogen and argon are presented in Table IV. The XRD spectra of samples reduced in helium were similar to those obtained in argon.

After 5 minutes of reduction in hydrogen, the reduced sample contained $\mathrm{TiO}_{2}, \mathrm{FeTiO}_{3}$, and some amount of metallic iron. After 15 minutes, both $\mathrm{TiO}_{2}$ and $\mathrm{FeTiO}_{3}$ phases disappeared, and correspondingly, a significant amount of $\mathrm{Ti}_{3} \mathrm{O}_{5}, \mathrm{Ti}_{2} \mathrm{O}_{3}$ and metallic iron was detected. It should be noted that it took about 15 to 20 minutes for the sample temperature to reach the experimental value, so the reaction within the first 15 to 20 minutes occurred at temperatures below $1100{ }^{\circ} \mathrm{C}$. $\mathrm{TiO}_{x} \mathrm{C}_{y}$ phase was observed at 30 minutes, when $\mathrm{Ti}_{3} \mathrm{O}_{5}$ was further converting to $\mathrm{Ti}_{2} \mathrm{O}_{3}$. After 240 minutes of reaction, when $\mathrm{Ti}_{3} \mathrm{O}_{5}$ was totally reduced, titanium oxycarbide became the major phase containing titanium coexisting with small amount of $\mathrm{Ti}_{2} \mathrm{O}_{3}$. After 300 minutes of reduction, the sample consisted of metallic $\mathrm{Fe}, \mathrm{TiO}_{x} \mathrm{C}_{y}$, $\mathrm{Ti}_{2} \mathrm{O}_{3}$, and residual carbon.

The carbothermal reduction of primary ilmenite concentrate in argon and helium followed the same sequence but progressed slower than in hydrogen,

Table IV. Phase Composition of Primary Ilmenite in Progress of Reduction in Hydrogen at $1100{ }^{\circ} \mathrm{C}$ and $\mathrm{Argon}$ at $1300{ }^{\circ} \mathrm{C}$

\begin{tabular}{|c|c|c|c|c|c|c|c|c|}
\hline Time, $\min$ & 5 & 15 & 30 & 60 & 120 & 180 & 240 & 300 \\
\hline $\mathrm{H}_{2}$ & $\begin{array}{l}\mathrm{C} \\
\mathrm{Fe} \\
\mathrm{FeTiO}_{3} \\
\mathrm{TiO}_{2}\end{array}$ & $\begin{array}{l}\mathrm{C} \\
\mathrm{Fe} \\
\mathrm{Ti}_{3} \mathrm{O}_{5} \\
\mathrm{Ti}_{2} \mathrm{O}_{3}\end{array}$ & $\begin{array}{l}\mathrm{C} \\
\mathrm{Fe} \\
\mathrm{Ti}_{2} \mathrm{O}_{3} \\
\mathrm{TiO}_{x} \mathrm{C}_{y} \\
\mathrm{Ti}_{3} \mathrm{O}_{5}\end{array}$ & $\begin{array}{l}\mathrm{C} \\
\mathrm{Fe} \\
\mathrm{Ti}_{2} \mathrm{O}_{3} \\
\mathrm{TiO}_{x} \mathrm{C}_{y}\end{array}$ & $\begin{array}{l}\mathrm{C} \\
\mathrm{Fe} \\
\mathrm{TiO}_{x} \mathrm{C}_{y} \\
\mathrm{Ti}_{2} \mathrm{O}_{3}\end{array}$ & $\begin{array}{l}\mathrm{C} \\
\mathrm{Fe} \\
\mathrm{TiO}_{x} \mathrm{C}_{y} \\
\mathrm{Ti}_{2} \mathrm{O}_{3}\end{array}$ & $\begin{array}{l}\mathrm{Fe} \\
\mathrm{TiO}_{x} \mathrm{C}_{y} \\
\mathrm{C} \\
\mathrm{Ti}_{2} \mathrm{O}_{3}\end{array}$ & $\begin{array}{l}\mathrm{Fe} \\
\mathrm{TiO}_{x} \mathrm{C}_{y} \\
\mathrm{C} \\
\mathrm{Ti}_{2} \mathrm{O}_{3}\end{array}$ \\
\hline $\mathrm{Ar}$ & $\begin{array}{l}\mathrm{C} \\
\mathrm{FeTiO}_{3} \\
\mathrm{TiO}_{2}\end{array}$ & $\begin{array}{l}\mathrm{C} \\
\mathrm{Fe} \\
\mathrm{Ti}_{3} \mathrm{O}_{5} \\
\mathrm{FeTiO}_{3}\end{array}$ & $\begin{array}{l}\mathrm{C} \\
\mathrm{Fe} \\
\mathrm{Ti}_{3} \mathrm{O}_{5} \\
\mathrm{Ti}_{2} \mathrm{O}_{3}\end{array}$ & $\begin{array}{l}\mathrm{C} \\
\mathrm{Fe} \\
\mathrm{Ti}_{3} \mathrm{O}_{5} \\
\mathrm{Ti}_{2} \mathrm{O}_{3}\end{array}$ & $\begin{array}{l}\mathrm{C} \\
\mathrm{Fe} \\
\mathrm{Ti}_{2} \mathrm{O}_{3} \\
\mathrm{TiO}_{x} \mathrm{C}_{y} \\
\mathrm{Ti}_{3} \mathrm{O}_{5}\end{array}$ & $\begin{array}{l}\mathrm{C} \\
\mathrm{Fe} \\
\mathrm{Ti}_{2} \mathrm{O}_{3} \\
\mathrm{TiO}_{x} \mathrm{C}_{y} \\
\mathrm{Ti}_{3} \mathrm{O}_{5}\end{array}$ & $\begin{array}{l}\mathrm{C} \\
\mathrm{Fe} \\
\mathrm{Ti}_{2} \mathrm{O}_{3} \\
\mathrm{TiO}_{x} \mathrm{C}_{y} \\
\mathrm{Ti}_{3} \mathrm{O}_{5}\end{array}$ & $\begin{array}{l}\mathrm{C} \\
\mathrm{Fe} \\
\mathrm{TiO}_{x} \mathrm{C}_{y} \\
\mathrm{Ti}_{2} \mathrm{O}_{3} \\
\mathrm{Ti}_{3} \mathrm{O}_{5}\end{array}$ \\
\hline
\end{tabular}

Note: The phases are presented in descending order in accordance with the relative intensity of XRD strongest peaks of individual phases. 
although the temperature was raised to $1300{ }^{\circ} \mathrm{C}$. As shown in Table IV, after 5 minutes of reduction in argon at $1300{ }^{\circ} \mathrm{C}$, the main phases were ilmenite and $\mathrm{TiO}_{2}$. No peaks for $\mathrm{Fe}_{2} \mathrm{Ti}_{3} \mathrm{O}_{9}$ were identified, and no metallic iron was observed. $\mathrm{Ti}_{3} \mathrm{O}_{5}$ and metallic $\mathrm{Fe}$ were formed after 15 minutes, whereas the ilmenite phase was not completely depleted. Extending reduction to 30 minutes completed the reduction of ilmenite. The conversion of $\mathrm{Ti}_{3} \mathrm{O}_{5}$ to $\mathrm{Ti}_{2} \mathrm{O}_{3}$ started from 30 minutes and lasted the whole following period of reduction without completion at 300 minutes. $\mathrm{TiO}_{x} \mathrm{C}_{y}$ was first observed at 120 minutes with increasing amount along with progress of reduction. After 300 minutes of reduction, the reduced sample contained metallic iron, $\mathrm{TiO}_{x} \mathrm{C}_{y}$, residual $\mathrm{Ti}_{3} \mathrm{O}_{5}, \mathrm{Ti}_{2} \mathrm{O}_{3}$, and graphite.

Table $\mathrm{V}$ presents the extent of reduction and composition of samples reduced at different temperatures for various time in hydrogen. The titanium oxycarbide composition was calculated only for samples when no titanium suboxides were detected by XRD. The titanium oxycarbide produced by reduction at $1200{ }^{\circ} \mathrm{C}$ for 300 minutes contained $15.8 \mathrm{~mol}$ pct $\mathrm{TiO}$. When the reduction temperature increased to $1300^{\circ} \mathrm{C}$, the $\mathrm{TiO}$ content in the titanium oxycarbide was $31.6 \mathrm{~mol}$ pet after 30 minutes. The $\mathrm{TiO}$ content decreased to 26.4 and $21.9 \mathrm{~mol}$ pet with increasing reduction time to 60 and 120 minutes, respectively. Finally, the $\mathrm{TiO}$ content decreased to $10.1 \mathrm{~mol}$ pct with increasing reduction time to 300 minutes. At $1400{ }^{\circ} \mathrm{C}$, the titanium oxycarbide contained up to $27.4 \mathrm{~mol}$ pet $\mathrm{TiO}$ after 30 minutes of reduction and 10 mol pet after 300 minutes. At $1500{ }^{\circ} \mathrm{C}$, titanium oxycarbide with $24.1 \mathrm{~mol}$ pct $\mathrm{TiO}$ was obtained after 30 minutes reduction. The $\mathrm{TiO}$ content was reduced to $14.7 \mathrm{~mol}$ pct after 60 minutes and $8.6 \mathrm{~mol}$ pct after 300 minutes. The oxygen content in the titanium oxycarbide decreased by either extending the reduction time or increasing the reduction temperature. Increasing the reduction temperature was more effective than extending reduction time.

Table V. Extent of Reduction and Titanium Oxycarbide Composition of Primary Ilmenite Reduced in Hydrogen

\begin{tabular}{lccc}
\hline $\begin{array}{l}\text { Reduction } \\
\text { temperature, } \\
{ }^{\circ} \mathrm{C}\end{array}$ & $\begin{array}{c}\text { Reduction } \\
\text { time, min }\end{array}$ & $\begin{array}{c}\text { Extent } \\
\text { of reduction, } \\
\text { pct }\end{array}$ & Composition \\
\hline 1200 & 300 & 95.0 & $\mathrm{TiO}_{0.158} \mathrm{C}_{0.842}$ \\
1300 & 30 & 89.6 & $\mathrm{TiO}_{0.316} \mathrm{C}_{0.684}$ \\
1300 & 60 & 91.3 & $\mathrm{TiO}_{0.264} \mathrm{C}_{0.736}$ \\
1300 & 120 & 93.2 & $\mathrm{TiO}_{0.219} \mathrm{C}_{0.781}$ \\
1300 & 180 & 94.6 & $\mathrm{TiO}_{0.197} \mathrm{C}_{0.803}$ \\
1300 & 240 & 95.0 & $\mathrm{TiO}_{0.151} \mathrm{C}_{0.849}$ \\
1300 & 300 & 96.6 & $\mathrm{TiO}_{0.101} \mathrm{C}_{0.899}$ \\
1400 & 30 & 91.0 & $\mathrm{TiO}_{0.274} \mathrm{C}_{0.726}$ \\
1400 & 60 & 93.8 & $\mathrm{TiO}_{0.189} \mathrm{C}_{0.811}$ \\
1400 & 300 & 97.0 & $\mathrm{TiO}_{0.100} \mathrm{C}_{0.900}$ \\
1500 & 30 & 94.0 & $\mathrm{TiO}_{0.192} \mathrm{C}_{0.808}$ \\
1500 & 60 & 95.2 & $\mathrm{TiO}_{0.147} \mathrm{C}_{0.853}$ \\
1500 & 300 & 97.5 & $\mathrm{TiO}_{0.086} \mathrm{C}_{0.914}$ \\
\hline
\end{tabular}

\section{DISCUSSION}

The ilmenite concentrate consisted of mainly ilmenite and pseudorutile phases. An analysis of phases in progress of carbothermal reduction showed that the reaction started with reduction of pseudorutile to ilmenite and titania, followed by the subsequent reduction of ilmenite to metallic iron and titania. Titania was reduced to $\mathrm{Ti}_{3} \mathrm{O}_{5}$ and then to $\mathrm{Ti}_{2} \mathrm{O}_{3}$, which was converted to titanium oxycarbide. The above sequence of reduction was followed both in hydrogen and in inert gases, argon, and helium.

Gas atmosphere and temperature had pronounced effects on the rate and extent of the carbothermal reduction of the primary ilmenite concentrate. The extent of reduction of ilmenite in different gases at various temperatures for 300 minutes is presented in Figure 6. In hydrogen, increasing temperature from $1000{ }^{\circ} \mathrm{C}$ to $1200{ }^{\circ} \mathrm{C}$ increased the extent of reduction from 68 pct to 95 pct. Further increase in temperature to $1500{ }^{\circ} \mathrm{C}$ had a marginal effect on the extent of reduction. In argon and helium, the extent of reduction was below 40 pct at $1000{ }^{\circ} \mathrm{C}$ to $1200{ }^{\circ} \mathrm{C}$. The complete conversion of titanium oxides to oxycarbide needed $1400{ }^{\circ} \mathrm{C}$ to $1500{ }^{\circ} \mathrm{C}$.

Pseudorutile in ilmenite ore contains hydrated water; however, a negligible amount of water was released in the course of reduction of primary ilmenite concentrate in argon or helium. This means that water was removed when the ore was processed to the dry concentrate. Therefore, in reduction experiments in hydrogen, water was formed as a result of reduction reactions. This was also confirmed by XRD analysis of ilmenite concentrate in the progress of reduction.

Hydrogen played a major role in the reduction of pseudorutile and ilmenite to metallic iron and titania, as well as the subsequent reduction of titania to $\mathrm{Ti}_{2} \mathrm{O}_{3}$ (Figures 1 and 3). The maximum rate of reduction of iron oxides corresponded to a temperature of $630{ }^{\circ} \mathrm{C}$ (Figure 1).

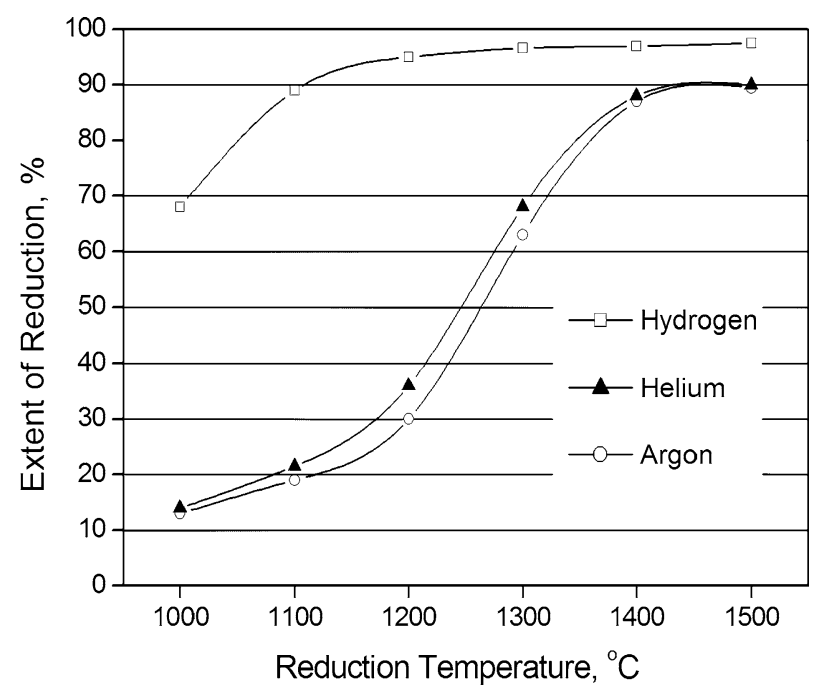

Fig. 6-Comparison of the extent of reduction of primary ilmenite in different gas atmospheres at various temperatures. Reduction period was $300 \mathrm{~min}$. 
A thermodynamic analysis of reduction of iron oxides by carbon shows that the reduction is feasible at similar low temperatures. The equilibrium temperature for reaction [5] under standard conditions calculated using data $^{[23]}$ is $667^{\circ} \mathrm{C}$. This means that at temperatures above $667{ }^{\circ} \mathrm{C}$ reduction of iron oxides to metallic iron by carbon is thermodynamically preferable in comparison with reduction by hydrogen. However, the reduction of pseudorutile was not observed in reduction experiments in argon and helium until $880{ }^{\circ} \mathrm{C}$ (Figure 1), and peaks for metallic iron were undetectable even at $1000{ }^{\circ} \mathrm{C}$ (Table II). The direct reduction by carbon is initiated at the contact points between metal oxides and carbon particles. The subsequent reaction between the solid phases proceeds through the gas phase:

$$
\begin{gathered}
\mathrm{Fe}_{2} \mathrm{Ti}_{3} \mathrm{O}_{9}+\mathrm{CO} \rightarrow 2 \mathrm{FeTiO}_{3}+\mathrm{TiO}_{2}+\mathrm{CO}_{2} \\
\mathrm{FeTiO}_{3}+\mathrm{CO} \rightarrow \mathrm{Fe}+\mathrm{TiO}_{2}+\mathrm{CO}_{2} \\
\mathrm{CO}_{2}+\mathrm{C}=2 \mathrm{CO}
\end{gathered}
$$

As shown by reactions [9] through [11], the oxides are reduced by $\mathrm{CO}$, which is regenerated by a reaction with carbon. However, reaction [11] needs elevated temperatures to proceed, which explains why the reduction of pseudorutile and ilmenite was not observed in the sample reduced in inert atmosphere at temperature below $880{ }^{\circ} \mathrm{C}$.

The subsequent reduction of $\mathrm{TiO}_{2}$ to $\mathrm{Ti}_{3} \mathrm{O}_{5}$ and $\mathrm{Ti}_{2} \mathrm{O}_{3}$ and the conversion of $\mathrm{Ti}_{2} \mathrm{O}_{3}$ to titanium oxycarbide in argon and helium also proceed through the gas phase. $\mathrm{Ti}_{2} \mathrm{O}_{3}$ is reduced to $\mathrm{TiO}$ and $\mathrm{TiC}$, which form a solid solution by reactions [12] and [13].

$$
\begin{gathered}
\mathrm{Ti}_{2} \mathrm{O}_{3}+\mathrm{CO}=2[\mathrm{TiO}]_{\mathrm{ss}}+\mathrm{CO}_{2} \\
\mathrm{Ti}_{2} \mathrm{O}_{3}+7 \mathrm{CO}=2[\mathrm{TiC}]_{\mathrm{ss}}+5 \mathrm{CO}_{2}
\end{gathered}
$$

When the reduction is carried out in hydrogen or hydrogen containing gas, hydrogen is involved in reduction reactions [1] through [5]. It also reacts with graphite to form methane:

$$
\mathrm{C}+2 \mathrm{H}_{2}=\mathrm{CH}_{4}
$$

The methane can reduce titanium oxide to oxycarbide:

$$
\begin{gathered}
\mathrm{Ti}_{2} \mathrm{O}_{3}+\mathrm{CH}_{4}=2[\mathrm{TiO}]_{\mathrm{ss}}+\mathrm{CO}+2 \mathrm{H}_{2} \\
\mathrm{Ti}_{2} \mathrm{O}_{3}+5 \mathrm{CH}_{4}=2[\mathrm{TiC}]_{\mathrm{ss}}+3 \mathrm{CO}+10 \mathrm{H}_{2}
\end{gathered}
$$

The formation of reaction intermediates $\mathrm{CH}_{4}$ or $\mathrm{CO}_{2}$ in the carbothermal reduction does not change the thermodynamics of related reduction reactions, but it affects the reaction kinetics. The thermodynamic analysis of reduction reactions presented in Reference 19 showed that the concentration of $\mathrm{CH}_{4}$ is by 4 to 5 orders higher than that of $\mathrm{CO}_{2}$. This explains why the carbothermal reduction was much faster in hydrogen than in argon and helium.

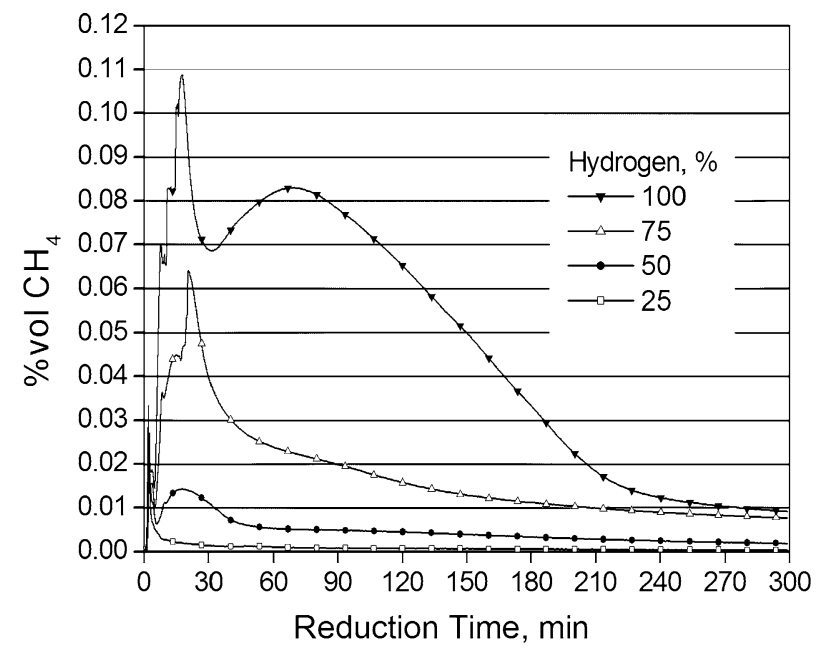

Fig. 7 - Concentration of $\mathrm{CH}_{4}$ in the off-gas in the process of carbothermal reduction of primary ilmenite in hydrogen-argon gas mixtures at $1300{ }^{\circ} \mathrm{C}$.

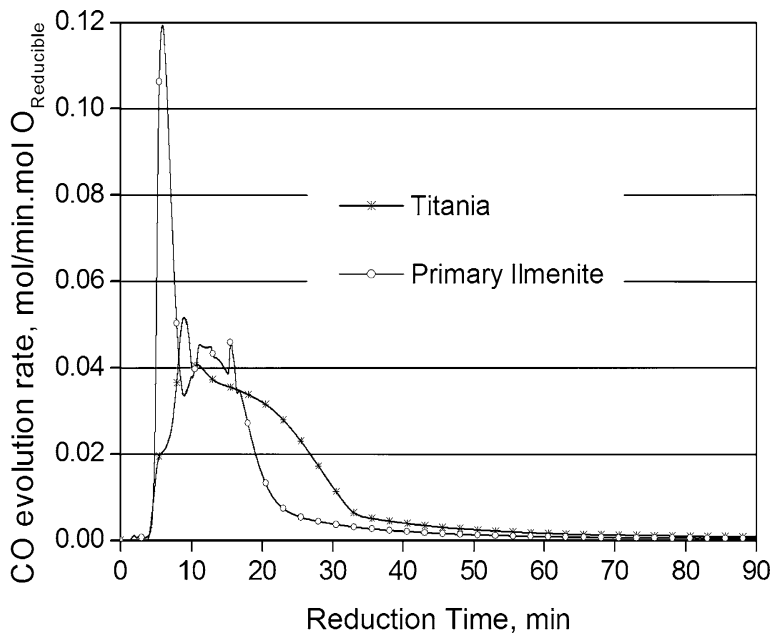

(a) Hydrogen

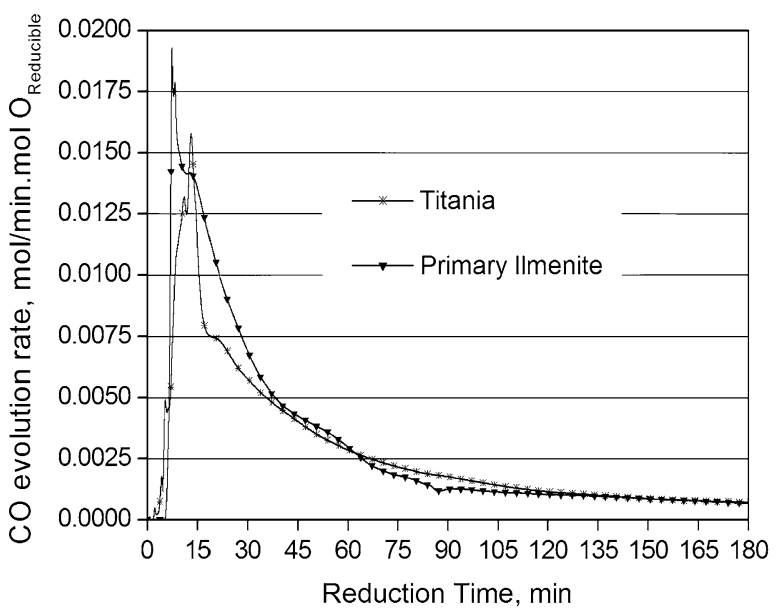

(b) Argon

Fig. 8- CO evolution rate during reduction of titania and primary ilmenite at $1300{ }^{\circ} \mathrm{C}$ in different gas atmospheres. 


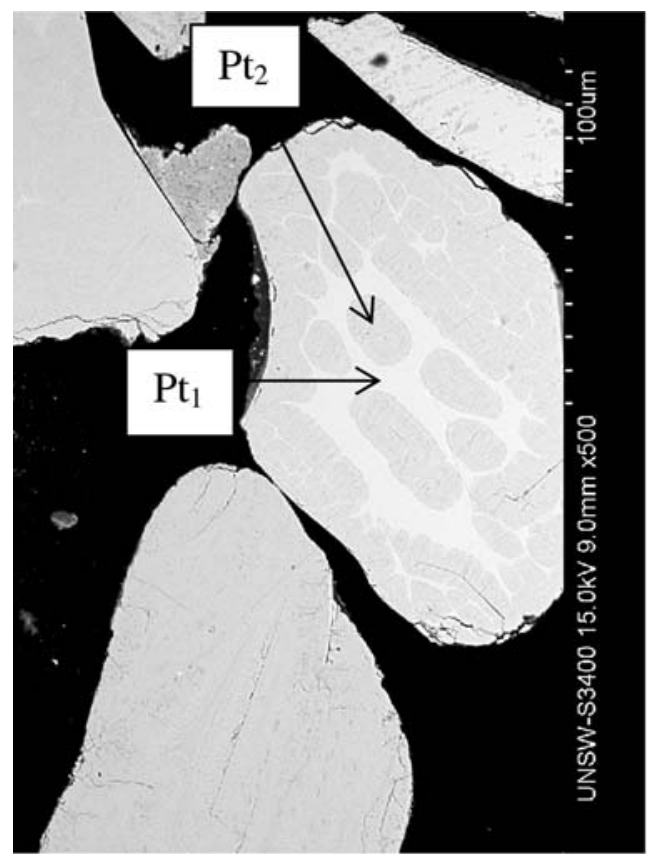

(a)

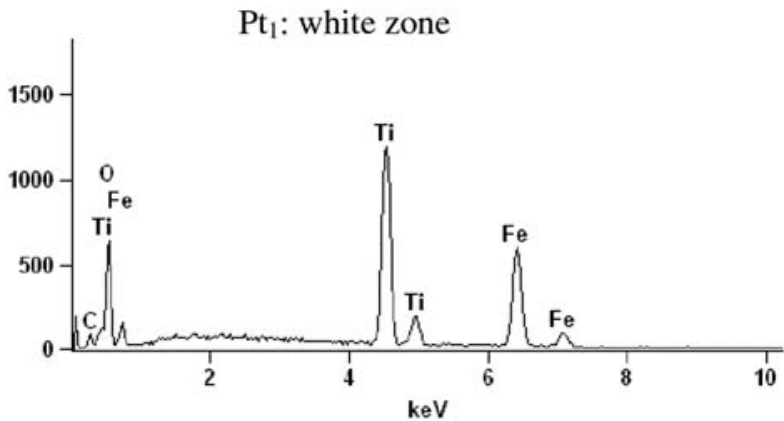

$\mathrm{Pt}_{2}$ : gray zone

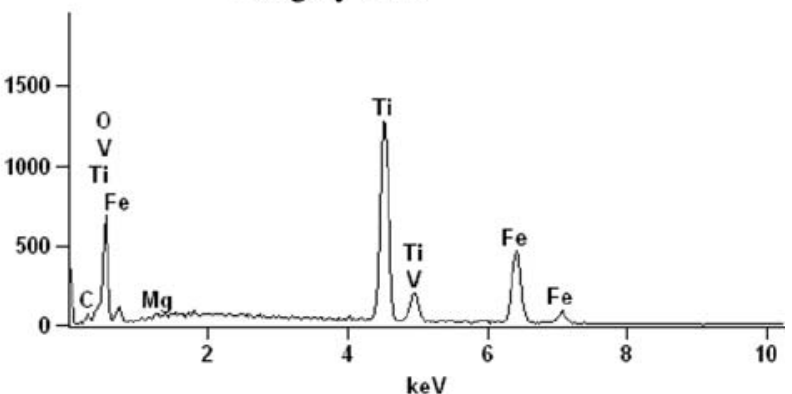

$\mathrm{Pt}_{1}$ : Fe rich zone
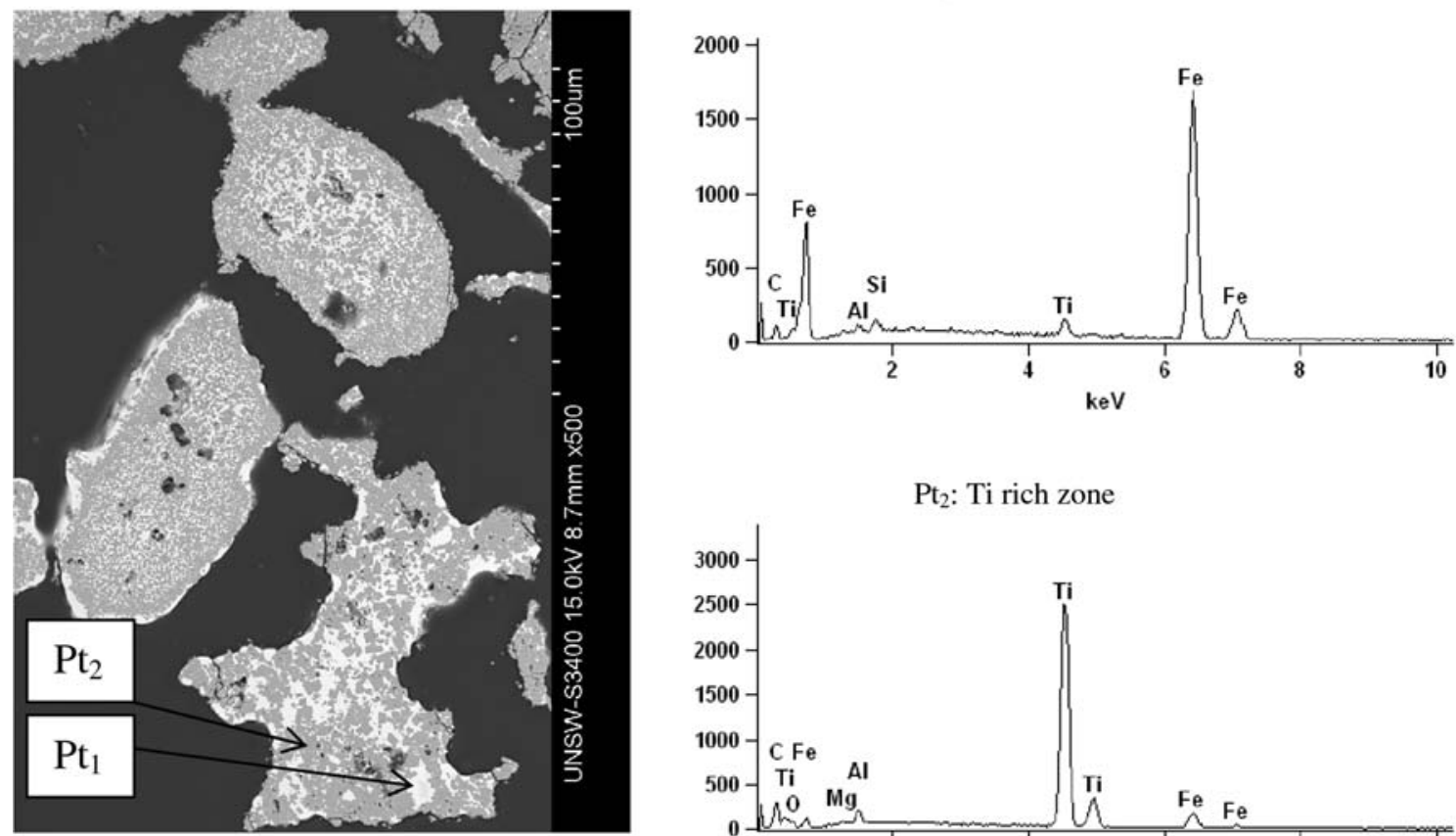

$\mathrm{Pt}_{2}$ : Ti rich zone

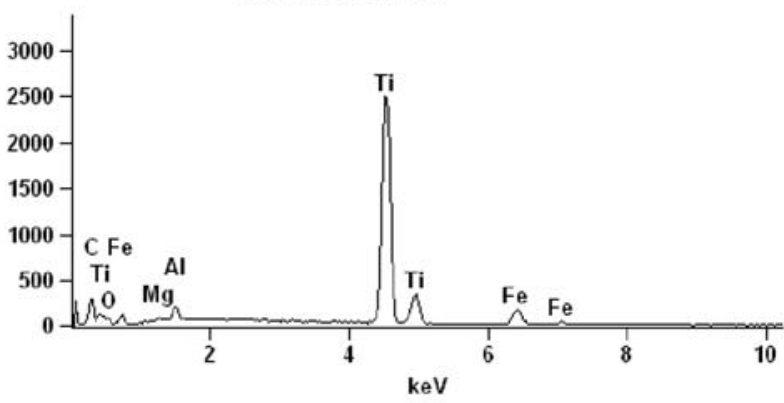

Fig. 9-BSE images and EDS analysis of unreduced and reduced primary ilmenite. Samples were reduced at $1300{ }^{\circ} \mathrm{C}$ for 300 min in different gases. (a) Unreduced ilmenite; $(b)$ reduced in hydrogen; $(c)$ reduced in argon; and (d) reduced in helium.

The formation of methane in the reduction experiments in hydrogen was confirmed experimentally by analyzing the off-gas composition. At $1300^{\circ} \mathrm{C}$, the methane content was measured to be more than
$1000 \mathrm{ppm}$. The observed change of methane content during reduction with hydrogen content in hydrogenargon mixtures is presented in Figure 7. Increasing partial pressure of hydrogen increases equilibrium 


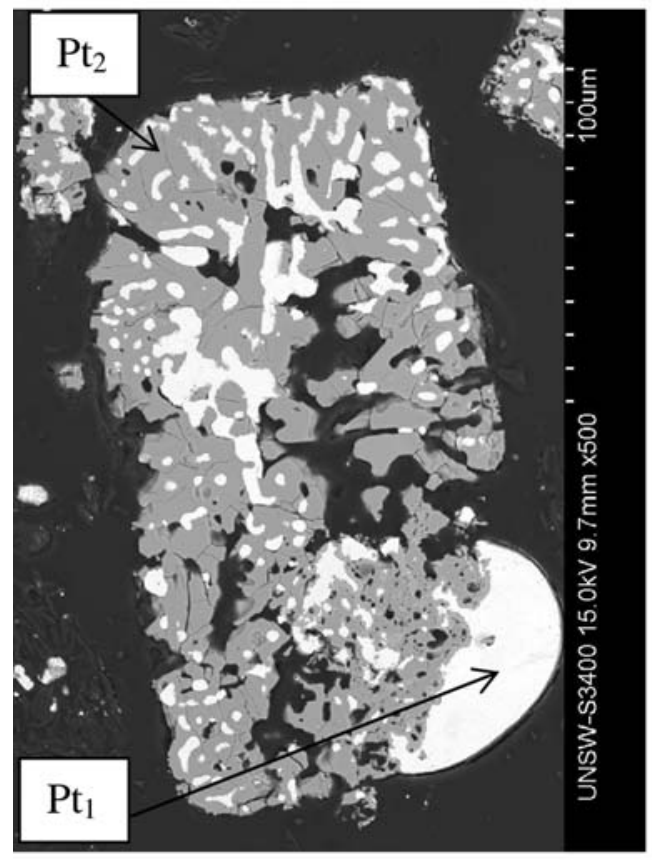

(c)

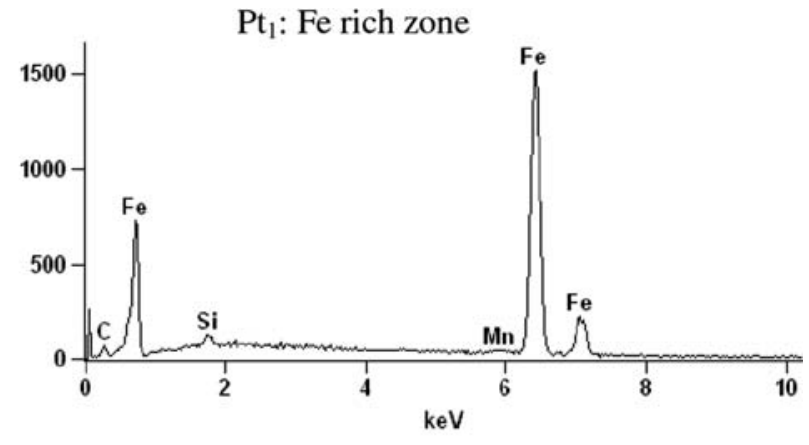

$\mathrm{Pt}_{2}$ : Ti rich zone

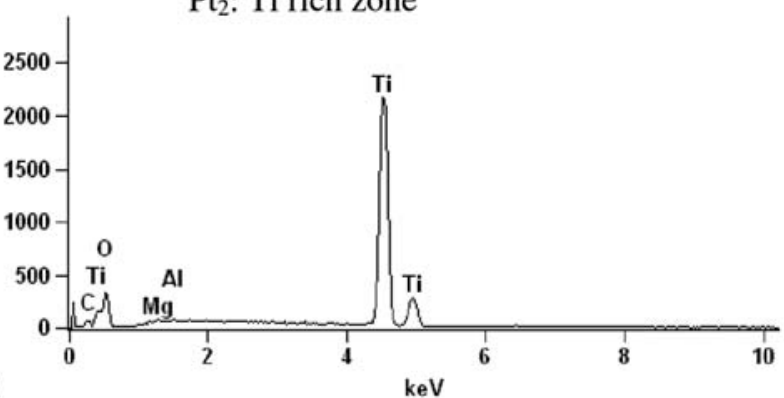

$\mathrm{Pt}_{1}$ : Fe rich zone
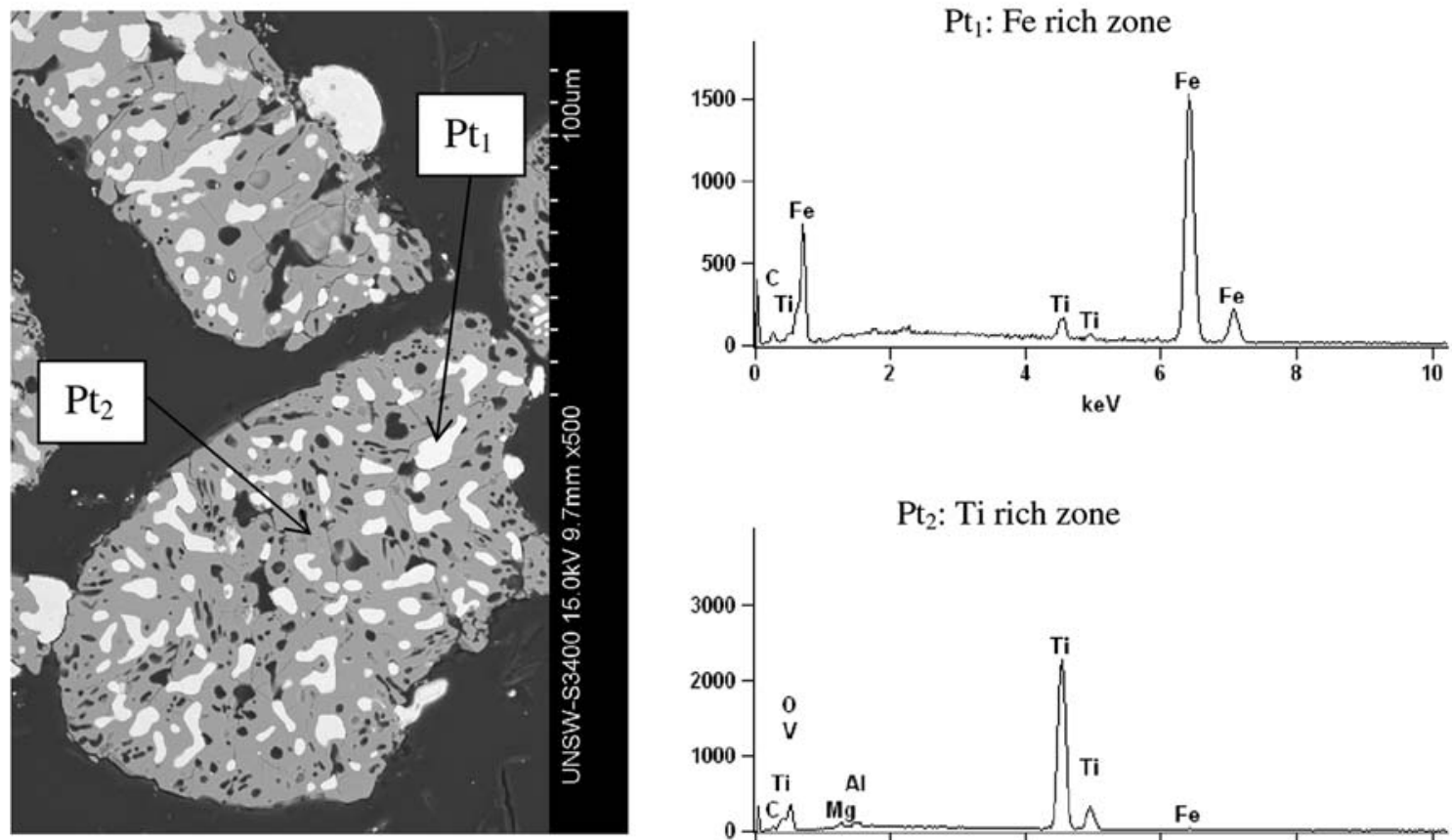

$\mathrm{Pt}_{2}$ : Ti rich zone

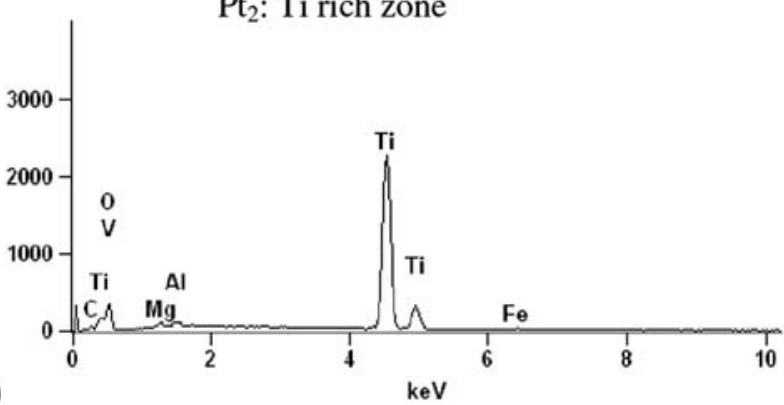

Fig. 9-Continued.

partial pressure of methane, and it enhances the formation of titanium oxycarbide in the course of carbothermal reduction of ilmenite concentrate.

Figure 8 compares the $\mathrm{CO}$ evolution rates during reduction of the primary ilmenite concentrate and titania at $1300{ }^{\circ} \mathrm{C}$ in hydrogen and argon. The rate of reduction in hydrogen can still be represented by the $\mathrm{CO}$ evolution rate because, at a high temperature, the water content in the off-gas was low. In Figure 8(a), the reduction curve for ilmenite concentrate shows two stages, with the first stage being the fast reduction of iron oxides to metallic iron. The formation of titanium oxycarbide at the second stage was also faster in the case of ilmenite concentrate: It was completed in about 
25 minutes for ilmenite concentrate and 35 minutes for pure titania. When the reduction was in an inert gas (Figure $8(b)$ ), the difference in reduction rates for ilmenite concentrate and pure titania was much smaller. Especially at the later stage of the reduction process when titanium oxides were converted to titanium oxycarbide, the $\mathrm{CO}$ evolution rates for titania and ilmenite were close.

Figure 9 presents the back-scattered electron (BSE) images of the primary ilmenite concentrate before reduction and reduced in different atmospheres. Although the BSE images show two zones of distinct contrast in the ilmenite concentrate prior to reduction, their EDS spectra were very similar, showing no significant difference in titanium and iron contents between the zones (Figure 9(a)). After reduction in hydrogen, fine grains of metallic iron were uniformly distributed within the matrix of titanium rich phase (Figure 9(b)). When the reduction was in argon and helium (Figures 9(c) and 9(d)), iron phase was coarse and formed globules. This can be explained by slow rate of metallization of iron in the inert gas atmosphere, resulted in fewer nuclei and their growth.

\section{CONCLUSIONS}

The results of a study of carbothermal reduction of a primary ilmenite concentrate by temperature programmed reduction and isothermal reduction experiments at $1000{ }^{\circ} \mathrm{C}$ to $1500{ }^{\circ} \mathrm{C}$ in different gas atmospheres can be summarized as follows.

1. The main phases in the primary ilmenite were pseudorutile and ilmenite.

2. Pseudorutile was first reduced to ilmenite and titania, followed by the reduction of ilmenite to metallic iron and titania. Titania was reduced to $\mathrm{Ti}_{3} \mathrm{O}_{5}$ and then $\mathrm{Ti}_{2} \mathrm{O}_{3}$, which was converted to titanium oxycarbide.

3. The carbothermal reduction of primary ilmenite concentrate was faster in hydrogen and occurred at a lower temperature than in argon and helium. The reduction in argon and helium had about the same rate and extent.

4. Titanium oxycarbide started to form at $1000{ }^{\circ} \mathrm{C}$ in hydrogen. The conversion of primary ilmenite concentrate to metallic iron and titanium oxycarbide at $1200{ }^{\circ} \mathrm{C}$ was complete in 300 minutes. This period was reduced to 90 minutes at $1300{ }^{\circ} \mathrm{C}, 60$ minutes at $1400{ }^{\circ} \mathrm{C}$, and 30 minutes at $1500^{\circ} \mathrm{C}$.

5. In a carbothermal reduction in argon and helium, titanium oxycarbide started to form at $1200{ }^{\circ} \mathrm{C}$. The conversion of titania to titanium oxycarbide was incomplete after 300 minutes reduction at $1300{ }^{\circ} \mathrm{C}$.

6. The faster reduction in hydrogen containing gas was attributed to the involvement of hydrogen in the reduction reactions. Iron oxides were directly reduced by hydrogen; hydrogen also reduced titania to $\mathrm{Ti}_{2} \mathrm{O}_{3}$. Methane formed by reacting hydrogen with carbon accelerated reduction of $\mathrm{Ti}_{2} \mathrm{O}_{3}$ to titanium oxycarbide.

7. In the reduction of primary ilmenite in hydrogen, metallic iron was in the form of fine grains which were distributed uniformly in the titanium oxycarbide matrix, while coarse globules were formed in the reduction of the ilmenite concentrate in argon and helium.

\section{ACKNOWLEDGMENTS}

This research was supported under Australian Research Council's Linkage Projects funding scheme (project number LP0455085). Professor Ostrovski is the recipient of an Australian Research Council Professorial Fellowship (project number DP0771059). The primary ilmenite concentrate was supplied by Iluka Resources Limited.

\section{REFERENCES}

1. C.S. Kucukkaragoz and R.H. Eric: Min. Eng., 2006, vol. 19, pp. 334-37.

2. S.K. Gupta, V. Rajakumar, and P. Grieveson: Metall. Trans. B, 1987, vol. 18 , pp. $713-18$.

3. J.B. Rosenbaum: J. Metals, 1982, vol. 34, pp. 76-80.

4. K.J. Stanaway: Min. Eng., 1994, vol. 46, pp. 1367-70.

5. Z.F. Yuan, X.Q. Wang, C. Xu, W.B. Li, and M. Kwauk: Min. Eng., 2006, vol. 19, pp. 975-78.

6. R. Merk and C.A. Pickles: Can. Metall. Q., 1988, vol. 27, pp. 17985.

7. Y. Chen, T. Hwang, and J.S. Williams: Mater. Letters, 1996, vol. 28 , pp. $55-58$.

8. E. Park and O. Ostrovski: ISIJ Int., 2003, vol. 43, pp. 1316-25.

9. E. Park and O. Ostrovski: ISIJ Int., 2004, vol. 44, pp. 999-1005.

10. A. Adipuri, G. Zhang, and O. Ostrovski: Metall. Mater. Trans. B, 2008, vol. 39, pp. 23-34.

11. K.S. Coley, B.S. Terry, and P. Grieveson: Metall. Mater. Trans. B, 1995, vol. 26, pp. 485-94.

12. B.S. Terry and O. Chinyamakobvu: Mater. Sci. Tech., 1991, vol. 7 , pp. 842-48.

13. Y. Wang and Z. Yuan: Int. J. Min. Pro., 2006, vol. 81, pp. 133-40.

14. N.J. Welham and J.S. Williams: Metall. Mater. Trans. B, 1999, vol. 30 , pp. $1075-81$.

15. G. Zhang and O. Ostrovski: Int. J. Min. Pro., 2002, vol. 64, p. 201.

16. G. Zhang and O. Ostrovski: Can. Metall. Q., 2001, vol. 40, pp. 489-97.

17. G. Zhang and O. Ostrovski: Can. Metall. Q., 2001, vol. 40, pp. 317-26.

18. Y.M. Wang and Z.F. Yuan: Int. J. Min. Pro., 2006, vol. 81, pp. $133-40$

19. M. Dewan, G. Zhang, and O. Ostrovski: Metall. Mater. Trans. B, 2009, vol. 40, pp. 62-69.

20. R. Kononov, O. Ostrovski, and S. Ganguly: Metall. Mater. Trans. B, 2008, vol. 39, pp. 662-68.

21. M. Yastreboff, O. Ostrovski, and S. Ganguly: ISIJ Int., 2003, vol. 43, pp. 161-65.

22. G. Zhang and O. Ostrovski: Metall. Mater. Trans. B, 2000, vol. 31, pp. 129-39.

23. E.T. Turkdogan: Physical Chemistry of High Temperature Technology, Academic Press, New York, NY, 1980. 